\title{
Compromised nutrition in gerbils infected by Cystoisospora felis detected through an animal performance analysis tool
}

Comprometimento nutricional em gerbis infectados por Cystoisospora felis detectado através de uma ferramenta de análise de desempenho animal

Edwards Frazão-Teixeira ${ }^{1}$; Francisco Carlos Rodrigues de Oliveira ${ }^{1}$; Vagner Ricardo da Silva Fiuza ${ }^{1}$; Amanda Lucía Jiménez-Sanz ${ }^{1}$; Edenio Detmann ${ }^{2}$

${ }^{1}$ Laboratório de Sanidade Animal, Universidade Estadual do Norte Fluminense Darcy Ribeiro - UENF

${ }^{2}$ Departamento de Zootecnia, Universidade Federal de Viçosa - UFV

Received February 11, 2011

Accepted July 28, 2011

\begin{abstract}
The impact of Cystoisospora felis infection on the nutritional efficiency of gerbils was studied. The variables weight gain and feed intake were measured during four weeks in 28 laboratory gerbils, of which 14 were inoculated with $3.5 \times 10^{5}$ sporulated oocysts of $C$. felis and the remaining 14 were controls. The animals from both groups were weighted, killed, eviscerated and had their carcasses and tissues weighted and compared. A modern tool designed for measuring nutritional performance of farm animals was applied. The results showed compromised nutritional efficiency of the infected animals within the first week after infection. The consequences of these results are discussed here, including the potential impact of infection on farm animals performance.
\end{abstract}

Keywords: Cystoisospora felis, gerbil, bio-nutritional index, farm animal, oocyst, BNI.

\section{Resumo}

O impacto da infecção por Cystoisospora felis na eficiência nutricional de gerbis foi estudado. As variáveis ganho de peso e consumo de ração foram mensuradas durante quatro semanas em 28 gerbis de laboratório, dos quais 14 foram inoculados com 3,5 $\times 10^{5}$ oocistos esporulados de $C$. felis e os 14 restantes serviram como controle. Os animais de ambos os grupos foram pesados, mortos, eviscerados e tiveram suas carcaças e tecidos pesados e comparados. Uma ferramenta moderna desenvolvida para mensurar o desempenho nutricional de animais de produçáo foi aplicada. Os resultados mostraram eficiência nutricional comprometida dos animais infectados na primeira semana após a infecção. As consequências destes resultados são discutidas aqui, incluindo o possível impacto de infecção no desempenho de animais de produção.

Palavras-chave: Cystoisospora felis, gerbil, índice bionutricional, animal de produção, oocisto, IBN.

\section{Introduction}

Cystoisospora felis is a coccidian that has domestic and wild felids as definitive hosts (HITCHCOCK, 1955; AMARAL et al., 1966; PATTON; RABINOWITZ, 1994) and several warmblooded animals as intermediate hosts, including mice, rats, hamsters (FRENKEL; DUBEY, 1972; FREIRE; LOPES, 1996), dogs (DUBEY, 1975), cattle (FAYER; FRENKEL, 1979), birds (LINDSAY; BLAGBURN, 1994), rabbits (COSTA; LOPES, 1998), pigs (MELO et al., 2003) and gerbils (CARVALHOFILHO et al., 2004). In general, the infection is not clinically

\footnotetext{
*Corresponding author: Edwards Frazão-Teixeira

Laboratório de Sanidade Animal,

Universidade Estadual do Norte Fluminense Darcy Ribeiro - UENF,

Campos dos Goytacazes, CEP 28013-602, Rio de Janeiro - RJ, Brazil;

e-mail: efrazao_teixeira@yahoo.com.br
}

manifested (MELO et al., 2003), although clinical signs have been observed in experimentally infected cats, mice and rabbits (LOSS; LOPES, 1992; FREIRE; LOPES, 1995; COSTA et al., 2006). The parasite has been proved to infect several extraintestinal tissues, including muscles, and researchers have focused their studies on infection of farm animals (MELO et al., 2003) and its potential negative impact on animal performance (COSTA et al., 2006). The main consequences of infection described have been reduced weight gain, markedly within the first week of infection, although in some cases carcass income may be affected up to one month after infection (COSTA et al., 2006). Additionally, the parasite can persist in the infected tissues even when there are no clinical signs (MELO et al., 2003), which shows the need to better assess the impact of infection on animal nutritional efficiency. 
The present study assessed the impact of $C$. felis infection in gerbils (Meriones unguiculatus) using a modern tool designed by Guidoni (1994) to analyze the nutritional efficiency of farm animals. Called bio-nutritional index (BNI) by Detmann et al. (2005) this tool allows to perform a bivariate analysis including weight gain and feed consumption, generating a canonical discriminator variable to estimate levels of performance.

\section{Material and Methods}

Oocysts of $C$. felis were concentrated from feces of a naturally infected cat litter seized by the Center for Zoonoses Control (CCZ) of the city of Campos dos Goytacazes, Rio de Janeiro state, Southeastern Brazil. The oocysts were sporulated in 2\% sulfuric acid, washed in phosphate-buffered saline (PBS) and counted using a Neubauer chamber. Twenty-eight gerbils were used in this experiment and divided by convenience (MEDRONHO et al., 2006) into two groups. In the infected group, 14 animals were inoculated orally with $3.5 \times 10^{5}$ oocysts. In the control group, the remaining 14 gerbils received PBS by the same via.

On Days seven, 14, 21 and 28 after inoculation, four, four, three and three animals respectively were weighted, killed, eviscerated and had their carcass and tissue specimens including spleen, liver, mesenteric lymph nodes, kidneys, gastrointestinal tract, heart and lungs weighted individually in a high-precision scale (Shimadzu Corporation, Kyoto, Japan). At the same time, 14, 10, six and three animals respectively had their feed intake and weight gain measured. These last two variables were combined in a bivariate analysis using the multivariate analysis of variance (MANOVA), as described by Detmann et al. (2005). The new variable, called BNI, and the means for each organ weight, animal live weight $(\mathrm{Lw})$, carcass weight $(\mathrm{Cw})$, total organ weight $(\mathrm{Ow})$, and their ratios $(\mathrm{Lw} / \mathrm{Cw}, \mathrm{Lw} / \mathrm{Ow}, \mathrm{Cw} / \mathrm{Ow})$ from both infected and control groups were compared through Student's $t$-test.

\section{Results}

On Day seven post-infection (PI) the BNI of the infected group was significantly lower compared to the control group $(\mathrm{p}<0.05)$ (Table 1). On Day 14 PI animals of the infected group had significantly higher live weights compared to the control group ( $\mathrm{p}<0.05$ ) (Table 2 ). Spleens were significantly enlarged on Days seven and 14 PI, as well as lungs on Day 14 PI. Also, the $\mathrm{Cw} / \mathrm{Ow}$ ratio was significantly lower on Day seven PI in the infected group.

\section{Discussion}

The significantly lower BNI found in the infected group indicated that $C$. felis infection caused reduced nutritional efficiency in gerbils within the first week after inoculation (Table 1). Although there was no significant impact on $\mathrm{Cw}$ or $\mathrm{Ow}$ separately, nonsignificant reduction of $\mathrm{Cw}$ and increase of $\mathrm{Ow}$ were potentized by $\mathrm{Cw} / \mathrm{Ow}$ ratio. This significantly lower ratio evidences a distancing between the low value of the numerator $(\mathrm{Cw})$ and the high value of the denominator $(\mathrm{Ow})$, therefore indicating impact on weight development as it shows the proportion in which the organs weight overcome the carcass weight of the infected animals within the first week post-infection (Table 2). During the second week post-infection there was no significant difference between BNI in both groups, suggesting good recovery of the infected animals. But although significantly higher live weight was seen in this group it may not be related to improved performance. There could be two rationales for it: the first, is a global organ enlargement, but only the spleen and lungs were significantly enlarged (Table 2) and thus it is not enough to explain significantly higher live weight; the second is the convenience distribution of the animals in the groups and low sample size, what may explain the significantly

Table 1. Bio-nutritional index (BNI) of gerbils (Meriones unguiculatus) inoculated with sporulated oocysts of Cystoisospora felis.

\begin{tabular}{|c|c|c|c|c|c|c|c|c|}
\hline \multirow{3}{*}{\multicolumn{2}{|c|}{ Data }} & \multicolumn{6}{|c|}{ Groups } & \multirow[t]{3}{*}{ p-value ${ }^{a}$} \\
\hline & & \multicolumn{3}{|c|}{ Infected } & \multicolumn{3}{|c|}{ Control } & \\
\hline & & $\mathbf{N}$ & Mean (g) & BNI & $\mathbf{n}$ & Mean $(\mathrm{g})$ & BNI & \\
\hline \multicolumn{9}{|l|}{ Week 1} \\
\hline & weight gain & & $-14.67 \pm 3.8859$ & & & $-9.79 \pm 6.877$ & & \\
\hline & & 14 & & 0.4314 & 14 & & 0.7113 & 0.0008 \\
\hline & feed intake & & $27.58 \pm 7.7185$ & & & $35.09 \pm 4.0165$ & & \\
\hline \multicolumn{9}{|l|}{ Week 2} \\
\hline & weight gain & & $0.16 \pm 4.1315$ & & & $-0.86 \pm 9.8100$ & & \\
\hline & & 10 & & 0.5859 & 10 & & 0.5508 & 0.7566 \\
\hline & feed intake & & $44.06 \pm 3.7482$ & & & $43.83 \pm 6.6069$ & & \\
\hline \multicolumn{9}{|l|}{ Week 3} \\
\hline & weight gain & & $2.46 \pm 4.6726$ & & & $2.02 \pm 1.4264$ & & \\
\hline & & 6 & & 1.4698 & 6 & & 1.3648 & 0.5780 \\
\hline & feed intake & & $47.73 \pm 8.1655$ & & & $46.51 \pm 7.3461$ & & \\
\hline \multicolumn{9}{|l|}{ Week 4} \\
\hline & weight gain & & $1.41 \pm 1.9443$ & & & $-0.55 \pm 0.9456$ & & \\
\hline & & 3 & & -1.8164 & 3 & & -2.6399 & 0.1138 \\
\hline & feed intake & & $40.81 \pm 8.3853$ & & & $40.46 \pm 5.2433$ & & \\
\hline
\end{tabular}

\footnotetext{
${ }^{a} \mathrm{P}$-value for Student's $t$-test.
} 
Table 2. Live, carcass and organ weights of gerbils (Meriones unguiculatus) inoculated with sporulated oocysts of Cystoisospora felis.

\begin{tabular}{|c|c|c|c|c|c|c|c|c|c|c|c|c|c|c|c|}
\hline \multirow[t]{2}{*}{ Day $\mathbf{P I}^{\mathbf{a}}$} & \multirow[t]{2}{*}{ Group } & \multirow[t]{2}{*}{$\mathbf{n}$} & \multicolumn{10}{|c|}{ Mean weights (g) and standard deviation } & \multicolumn{3}{|c|}{ Mean weight ratio } \\
\hline & & & Spleen & Liver & $\mathbf{M L}^{\mathbf{b}}$ & Kidneys & $\mathbf{G I}^{\mathbf{c}}$ & Heart & Lungs & $\mathbf{L w}^{\mathrm{d}}$ & $\mathrm{Cw}^{\mathrm{e}}$ & $\mathbf{O w}^{\mathrm{f}}$ & $\mathrm{Lw} / \mathrm{Cw}$ & $\mathrm{Lw} / \mathrm{Ow}$ & $\mathrm{Cw} / \mathrm{Ow}$ \\
\hline \multirow[t]{3}{*}{7} & Infected & 4 & 0.12 & 1.87 & 0.44 & 0.55 & 5.40 & 0.31 & 0.43 & 53.51 & 23.87 & 9.10 & 2.25 & 5.88 & 2.25 \\
\hline & & & \pm 0.02 & \pm 0.29 & \pm 0.13 & \pm 0.09 & \pm 0.88 & \pm 0.06 & \pm 0.13 & \pm 8.54 & \pm 4.52 & \pm 1.05 & \pm 0.14 & \pm 0.73 & \pm 0.14 \\
\hline & & & \pm 0.03 & \pm 0.24 & \pm 0.09 & \pm 0.09 & \pm 0.46 & \pm 0.04 & \pm 0.02 & \pm 8.06 & \pm 4.33 & \pm 0.68 & \pm 0.09 & \pm 0.59 & \pm 0.29 \\
\hline $\mathrm{p}$-value & & & 0.029 & 0.920 & 0.493 & 0.767 & 0.742 & 0.216 & 0.163 & 0.668 & 0.453 & 0.746 & 0.225 & 0.255 & 0.004 \\
\hline \multirow{2}{*}{14} & Control & 4 & 0.03 & 2.01 & 0.40 & 0.57 & 5.67 & 0.34 & 0.27 & 53.83 & 27.41 & 9.27 & 2.00 & 5.82 & 2.95 \\
\hline & & & \pm 0.01 & \pm 0.32 & \pm 0.05 & \pm 0.02 & \pm 0.39 & \pm 0.10 & \pm 0.08 & \pm 5.52 & \pm 5.96 & \pm 0.76 & \pm 0.25 & \pm 0.57 & \pm 0.52 \\
\hline $\mathrm{p}$-value & & & 0.001 & 0.444 & 0.113 & 0.408 & 0.399 & 0.503 & 0.048 & 0.019 & 0.431 & 0.226 & 0.272 & 0.187 & 0.995 \\
\hline \multirow[t]{2}{*}{21} & Infected & 3 & 0.08 & 2.08 & 0.39 & 0.57 & 5.93 & 0.28 & 0.37 & 63.47 & 30.52 & 9.70 & 2.08 & 6.56 & 3.15 \\
\hline & & & \pm 0.02 & \pm 0.09 & \pm 0.14 & \pm 0.01 & \pm 0.62 & \pm 0.01 & \pm 0.12 & \pm 4.49 & \pm 2.67 & \pm 0.79 & \pm 0.04 & \pm 0.46 & \pm 0.26 \\
\hline \multirow[t]{4}{*}{28} & Infected & 3 & 0.10 & 2.11 & 0.40 & 0.70 & 5.82 & 0.25 & 0.44 & 60.21 & 28.53 & 9.81 & 2.12 & 6.11 & 2.89 \\
\hline & & & \pm 0.03 & \pm 0.49 & \pm 0.12 & \pm 0.28 & \pm 0.08 & \pm 0.03 & \pm 0.07 & \pm 12.32 & \pm 6.44 & \pm 1.05 & \pm 0.05 & \pm 0.80 & \pm 0.44 \\
\hline & Control & 3 & 0.05 & 1.95 & 0.29 & 0.55 & 6.05 & 0.31 & 0.39 & 61.67 & 29.18 & 9.58 & 2.12 & 6.57 & 3.12 \\
\hline & & & \pm 0.02 & \pm 0.18 & \pm 0.04 & \pm 0.08 & \pm 1.53 & \pm 0.06 & \pm 0.03 & \pm 4.04 & \pm 3.15 & \pm 1.63 & \pm 0.12 & \pm 1.20 & \pm 0.71 \\
\hline p-value & & & 0.052 & 0.634 & 0.221 & 0.424 & 0.814 & 0.193 & 0.303 & 0.855 & 0.883 & 0.849 & 0.976 & 0.608 & 0.655 \\
\hline
\end{tabular}

${ }^{\mathrm{a}}$ Days post-infection. ${ }^{\mathrm{b}}$ Mesenteric lymph nodes. ${ }^{\mathrm{c}}$ Gastrointestinal tract. ${ }^{\mathrm{d}}$ Live weight. ${ }^{\mathrm{e}}$ Carcass weight. ${ }^{\mathrm{P}}$ Total organ weight.

lower spleen, lungs and live weight of the animals in the control group on Day 14 PI (Table 2).

Oliveira et al. (2007) observed that spleens of gerbils are parasitized only a few days after infection; in rabbits the spleen was reported to be more parasitized during the first week after infection (COSTA; LOPES, 1998). Also, Oliveira et al. (2001) apud Oliveira et al. (2002) inferred that extraintestinal hypnozoites might have caused an enlargement of viscera in mice infected with $C$. obioensis. These findings could explain the fact that in the present study the spleen was significantly enlarged in the infected animals within the first week after infection (Table 2). During the second week post-infection lungs were also significantly enlarged (Table 2), which is consistent with the literature as, although C. felis has a positive tropism to lymphoid tissues and skeletal muscles (FRENKEL; DUBEY, 1972; FREIRE; LOPES, 1996; MELO et al., 2003), monozoic cysts can form in other organs (MARKUS, 1976; LEVINE, 1985).

Within the third week post-infection the animals were fully recovered, which was evidenced by no significant differences in $\mathrm{BNI}$ and tissue weights between infected and control groups (Tables 1 and 2). Similar results were found in mice experimentally infected with C. felis (LOSS; LOPES, 1992). Despite the recovery seen in the infected gerbils, the study results point to nutritional compromising of these animals for at least one week. This could affect technically and economically high performance animals if they become infected during the production period (COSTA et al., 2006). Similar nutritional compromising was reported in meattype rabbits, which recovered only within week four after infection (COSTA et al., 2006). These authors reported, based on observations on the pair-fed group, that infection caused low feed intake and therefore compromised weight gain and feed conversion ratio (FCR). Anorexia and its nutritional consequences, along with increased organ size, have been directly associated to the progression of sporozoites into extraintestinal hypnozoites (COSTA; LOPES, 1998) and its metabolic wasting (LOSS; LOPES, 1992).

For many years nutritional efficiency of farm animals has been assessed by FCR or feed efficiency index (FEI). But, according to Guidoni (1994), these variables result in under- or overestimation, respectively, of nutritional performance of animals. Furthermore, their use is limited when analyzing data of low feed intake or negative values of income, as seen in the present study (Table 1). These negative numbers are incoherent biological values for FCR and FEI calculation, but BNI combines feed intake and weight gain into a new one-dimensional variable that encompasses their characteristics and prevents these problems (GUIDONI, 1994; DETMANN et al., 2005). This tool has been used to analyze the nutritional efficiency of high performance farm animals (EUCLIDES-FILHO et al., 2001; DETMANN et al., 2005; MELLO et al., 2010) and in this study we found that it is also valuable to assess the effects of parasitic infections on nutritional development, especially when there are no clinical signs.

\section{Conclusions}

Cystoisospora felis infection compromised the performance of gerbils within the first week after inoculation and the most affected organ was the spleen. The BNI tool successfully detected the impact of this infection on gerbils and should be used to assess the effects of parasitic infections on nutritional development of farm animals. 


\section{Acknowledgments}

This study was supported by Fundação Carlos Chagas Filho de Amparo à Pesquisa Científica do Estado do Rio de Janeiro (FAPERJ, process \# E-26/102.027/2009), Coordenação de Aperfeiçoamento de Pessoal de Nível Superior (CAPES) and Universidade Estadual do Norte Fluminense Darcy Ribeiro (UENF).

\section{References}

AMARAL, V.; AMARO, R. G.; BIRGEL, E. H. Ocorrência da Isospora felis Wenyon, 1923, em suçuarana (Puma concolor). Revista da Sociedade Paulista de Medicina Veterinária, v. 4, n. 1, p. 25-28, 1966.

CARVALHO-FILHO, P. R. et al. Cystoisospora felis e C. rivolta (Apicomplexa: Cystoisosporinae) em vísceras de gerbis da Mongólia (Meriones unguiculatus) e sua transmissão para gatos livres de coccídios. Revista Brasileira de Parasitologia Veterinária, v. 13, n. 4, p. 169-172, 2004.

COSTA, P. S.; LOPES, C. W. G. Avaliação do parasitismo por Cystoisospora felis (Wenyon, 1923) Frenkel, 1977 (Apicomplexa: Cystoisosporinae) em coelhos tipo carne. Revista Brasileira de Parasitologia Veterinária, v. 7 , n. 1, p. 15-19, 1998.

COSTA, P. S. et al. Alteraçôes clínicas observadas em coelhos, tipo carne, infectados experimentalmente com Cystoisospora felis (Wenyon, 1923) Frenkel, 1977 (Apicomplexa: Cystoisosporinae). Revista Brasileira de Parasitologia Veterinária, v. 15, n. 2, p. 80-84, 2006.

DETMANN, E. et al. Application of the first canonical variable in the evaluation of animal production trials. Revista Brasileira de Zootecnia, v. 34, n. 6, p. 2417-2426, 2005. http://dx.doi.org/10.1590/S151635982005000700030

DUBEY, J. P. Experimental Isospora canis and Isospora felis infection in mice, cats and dogs. Journal of Eukaryotic Microbiology, v. 22, n. 3, p. 416-417, 1975. http://dx.doi.org/10.1111/j.1550-7408.1975. tb05195.x

EUCLIDES-FILHO, K. et al. Eficiência Bionutricional de Animais Nelore e seus Mestiços com Simental e Aberdeen Angus, em Duas Dietas. Revista Brasileira de Zootecnia, v. 30, n. 1, p. 77-82, 2001. http://dx.doi.org/10.1590/S1516-35982001000100013

FAYER, R.; FRENKEL, J. K. Comparative infectivity for calves of oocysts of feline coccidia: Besnoitia, Hammondia, Cystoisospora, Sarcocystis and Toxoplasma. Journal of Parasitology, v. 65, n. 5, p. 756-762, 1979. PMid:117090. http://dx.doi.org/10.2307/3280357

FREIRE, R. B.; LOPES, C. W. G. Infecção experimental em camundongos neonatos com esporozoítas de Cystoisospora felis (Wenyon, 1923) Frenkel, 1977 (Apicomplexa: Sarcocystidae). Revista Brasileira de Ciência Veterinária, v. 2, n. 1, p. 33-34, 1995.

FREIRE, R. B.; LOPES, C. W. G. Distribuição de hipnozoítas de Cystoisospora felis (Wenyon, 1923) Frenkel, 1977 (Apicomplexa:
Sarcocystidae) em camundongos albinos experimentalmente infectados. Revista Brasileira de Parasitologia Veterinária, v. 5, n. 1, p. 23-28, 1996.

FRENKEL, J. K.; DUBEY, J. P. Rodents as vectors for feline Coccidia, Isospora felis and Isospora rivolta. Journal of Infectious Diseases, v. 125, n. 1, p. 69-72, 1972. PMid:5008695. http://dx.doi.org/10.1093/ infdis/125.1.69

GUIDONI, A. L. Alternativas para comparar tratamentos envolvendo o desempenho nutricional animal. 1994. 105 f. Tese (Doutorado em Agronomia)-Escola Superior de Agricultura Luiz de Queiroz, Universidade de São Paulo, Piracicaba.

HITCHCOCK, D. J. The life cycle of Isospora felis in the kitten. Journal of Parasitology, v. 41, n. 4, p. 383-397, 1955. PMid:13252514. http://dx.doi.org/10.2307/3274239

LEVINE, N. D. Veterinary Protozoology. Iowa: Iowa State University Press, $1985.414 \mathrm{p}$.

LINDSAY, D. S.; BLAGBURN, B. L. Biology of Mammalian Isospora. Parasitology Today, v. 10, n. 6, p. 214-220, 1994. http://dx.doi. org/10.1016/0169-4758(94)90116-3

LOSS, Z. G.; LOPES, C. W. G. Alguns aspectos clínicos da infecção experimental por Cystoisospora felis (Wenyon, 1923) Frenkel, 1977 (Apicomplexa:Cystoisosporinae) em gatos. Arquivos da Universidade Federal Rural do Rio de Janeiro, v. 15, n.1, p. 79-84, 1992.

MARKUS, M. B. A term for extra intestinal stages of mammalian Isospora (Protozoa, Coccidia, Eimeriidae). South Africa Journal of Science, v. 72, n. 6, p. 220, 1976

MEDRONHO, R. A. et al. Epidemiologia. São Paulo: Editora Atheneu, 2006. 493 p.

MELO, P. S. et al. Hypnozoites of Cystoisospora felis (Wenyon, 1923) Frenkel, 1977 (Apicomplexa: Cystoisosporinae) in swine (Sus scrofa domesticus) visceras: a new intermediated host. Revista Brasileira de Parasitologia Veterinária, v. 12, n. 3, p. 103-107, 2003.

MELLO, R. et al. Bionutritional efficiency of crossbred beef cattle finished on feedlot and slaughtered at different body weights. Revista Brasileira de Zootecnia, v. 39, n. 3, p. 582-593, 2010. http://dx.doi. org/10.1590/S1516-35982010000300018

OLIVEIRA, F. C. R. et al. Influência da infecção por Cystoisospora ohioensis (Dubey, 1975) Frenkel, 1977 no ganho de peso de camundongos albinos. Revista Brasileira de Parasitologia Veterinária, v. 11, n. 2, p. 103-107, 2002.

OLIVEIRA, F. C. R. et al. Hypnozoites of Cystoisospora Frenkel, 1977 (Apicomplexa: Cystoisosporinae) in Mongolian gerbil lymph nodes and their transmission to cats free of coccidia. Revista Brasileira de Parasitologia Veterinária, v. 16, n. 2, p. 72-76, 2007. PMid:17706007.

PATTON, S.; RABINOWITZ, A. R. Parasites of wild felidae in Thailand: a coprological survey. Journal of Wildlife Diseases, v. 30, n. 3, p. 472-475, 1994. PMid:7933301. 